\title{
A POSSIBLE CORRELATION BETWEEN MYOSTATIN AND TESTOSTERONE AIDED BY GENETIC FACTORS ENHANCING ATHLETIC PERFORMANCE AND MUSCLE RECOVERY
}

\section{Istanbul / Türkiye \\ p. $447-453$}

Received: 03/12/2021

Accepted: $19 / 12 / 2021$

Published: 01/01/2022

This article has been scanned I iThenticat No plagiarism detected

\author{
Abdul Razzaq Jabr AL MAJIDI ${ }^{1}$ \\ Rafia S. FATHI ${ }^{2}$ \\ Rehab S. RAMADHAN ${ }^{3}$
}

\begin{abstract}
:
Background: multiple factors can affect athletic performance including nutrition, environmental, physiological, physical fitness, and genetic factors. Hormonal factors such as testosterone, and myostatin (MSTN) or GDF8 can be named to show significant effect on muscle growth and recovery after intensive training. Illustrating the combined relationship between the latest factors may help in developing efficient program for athletic care and exceled performance.

Methods: participation in this work came from 67 male divided into two groups of 35 endurance and sprinters and 32 power athletes, with 36 females fall into two groups of 20 sprinters and 16 power athletes. Testosterone and MSTN levels were measured in both genders before, and after intensive training program followed by third measurement after 5 hours rest and recovery. The MSTN gene was analyzed for the presence of genetic polymorphism using specific PCR amplification.

Results: data obtained showed the presence of negative relationship between testosterone and MSTN, whereas genetic analysis showed presence of three genotypes with different frequencies each one of them affected MSTN with different rate ranging from normal production levels with normal function to lack of function found in power athletes showing speedup muscle recovery and higher muscle mass.

Conclusions: higher levels of testosterone reduced MSTN levels significantly showing negative correlation between them. Low expression or production of nonfunctional MSTN protein enhanced muscle recovery, higher muscle mass, and improved athletic performance.
\end{abstract}

Key words: MSTN, Testosterone, Athletic Performance, Athletic Genes.

http://dx.doi.org/10.47832/2717-8293.15.32

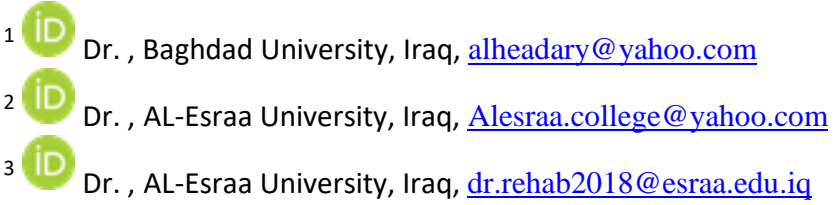




\section{Introduction}

Skeletal muscles is the system for movement, posture, and body functions that influence life and act as protein reservoir, contributing to homeostasis of blood sugar, generation of heat, metabolism regulating and health throughout life $[1,2]$. The endeavor to obtain increased lean body mass is a quest pursued by athletes practicing power sports such as football, rugby, and powerlifting. In addition, high quality and quantity of muscle mass is the critical issue among bodybuilders by which competitors are judged. On the other hand, muscle hypertrophy is also pursued by the many recreational lifters who desire to develop their physiques to the fullest. Therefore, variety of populations associated with sports and health were implicated [3]. High muscle mass is the major components for coping with various sports for the presence of strong correlation between muscle cross-sectional area and muscle strength $[4,5]$ taking in concern that correct ratio of muscle mass is an important factor from a health point of view since decreased muscle mass is associated with increased risks of several diseases such as cardiovascular disease [6,7], cardiometabolic risk in adults [8] and increased incidence of type II diabetes millets in middle aged and elderly people [9].

Myostatin, or can be named as growth-differentiation factor 8 (GDF8), is classified as member of the Transforming Growth Factor Beta (TGF- $\beta$ ) superfamily involved in wound healing, angiogenesis, immunoregulation and cancer that expressed mainly in muscle causing muscle growth inhibition [10,11]. When this factor losses its function due to gene mutations, an enhances muscle growth is initiated causing muscular hypertrophy, higher muscle mass showing no extra-muscular abnormalities, and explosive strength [12]. Few reports have evaluated serum myostatin normal levels and control in the general population associated with age, physiological status, with a drawback that it is made in small and nonrepresentative groups elaborating limited and inconsistent data. However, mechanical loading of skeletal muscle is thought to be the main and critical factors in the regulation of myostatin production $[13,14]$.

Most studies delt with testosterone considered it as one of the main anabolic hormones affecting skeletal muscle synthesis, recovery, and hypertrophy upon supplementation. It influences different physiological functions including sexual capability, systemic metabolism, cognitive function, as well as bone growth, development, and repair [15]. With its vital role in muscle growth, increased evidence that testosterone might involve in development of muscle mass in adults, adaptive growth in response to anabolic signals with increased load, maintenance of muscle mass after injury, and prevention of muscle mass loss due to cessation or lack of movement and aging [16]. However, the in skeletal muscle, testosterone found to be highly anabolic [17].

Elite athletes possess special characteristics appear to emerge from interaction among anatomical, metabolic, functional, or behavioral factors responding to exogenous influences of environmental factors [18] in addition to genetic interactions associated with physical performance. Among the many potential genes influencing athletic performance, low or lack of myostatin gene (MSTN) gene expression enhanced muscle development playing a negative role in this process whereas testosterone considered as positive regulator [19]. Genetic analysis of myostatin 5'-regulatory region, several binding sites for the androgen-receptor complex were found, giving the indication that testosterone may down-regulates the transcription of myostatin causing the reduction of myostatin content [20].

Thus, with our previous study [21], we aim to investigate the possible relationship between MSTN, testosterone, and presence of genetic polymorphism in exceled and elite athletes participated in this study.

\section{Methods}

\section{Study approval}

This study was approved by Scientific and Ethical Committee at Al-Esraa University College, Baghdad-Iraq as a part of selection program for elite athletes at the department of Physical Education.

\section{Participants}

Signed and written consent was obtained from all participants who ranged in age 18$25 \pm 5.6$ years old divided into 67 male stratified into two groups of 35 endurance and sprinters and 32 power athletes, 10 of them are local and regional championships winners, 
and 36 female fall into two groups of 20 sprinters and 16 power athletes, 3 of them with exceled winning history during local and regional tournaments. Control was 50 divided as 20 female and 30 males of the same age.

\section{Sample collection}

Blood samples of $5 \mathrm{ml}$ were collected from participants and kept in sterile tubes. Serum and WBCs were separated to be used for biochemical and genetic analysis. All samples were subjected to testosterone and MSTN measurement at the same day using Testosterone ELISA Kit (ab108666), Abcam, USA, and Human Myostatin (MSTN) ELISA Kit, Abbexa, UK respectively before and after active training session, while WBCs were the source for DNA extracted using Genaid Total DNA extraction kit, Korea as instructed by the company.

\section{MSTN gene amplification}

Four primers designed by [19] were used to cover the same sites constructing MSTN gene. PCR amplicons were resolved by $1.5 \%$ agarose for $90 \mathrm{~min}$. at field strength of $10 \mathrm{v} / \mathrm{cm}$. resulted PCR products were purified and cleaned using Favorgen PCR cleaning kit, Taiwan, then sent for sequencing by Macrogen, Korea.

\section{Data analysis}

Data obtained were subjected to statistical analysis using SPSS for windows version 21.00. $\mathrm{chi}^{2}$ was used to confirm the genotype frequencies were in Hardy-Weinberg equilibrium and comparing alleles and genotype frequencies between athletes and controls, and between athletes from different sports. Student's t-test was used for genotype indexes. Resulting data were represented by mean \pm standard deviation (SD). Differences among groups were considered as statistically significant when $p$-value was below 0.05 .

\section{Results}

Athletes are specific group among society characterized by special features such as height, power, endurance, muscularity, and tolerance to intense training. Response to training programs and intense exercise reflects it effect on body shape, muscles size, bone structure, and quantity of fats. Anthropometric data obtained from athletes studied are listed in table 1.

Table 1. Anthropometric data and phenotypic characteristics of athletes participated in the study.

\begin{tabular}{|l|l|l|l|l|}
\hline $\begin{array}{l}\text { Phenotypic } \\
\text { Characteristics }\end{array}$ & $\begin{array}{l}\text { Sprinters and Endurance } \\
\mathrm{N}=55\end{array}$ & $\begin{array}{l}\text { Power athletes } \\
\mathrm{N}=48\end{array}$ & $\begin{array}{l}\text { Control } \\
\mathrm{N}=50\end{array}$ & $\mathrm{p}$-Value \\
\hline Height, $\mathrm{cm}$ & $180.2 \pm 9.1$ & $177.8 \pm 8.7$ & $177.5 \pm 6.3$ & 0.597 \\
\hline Weight $(\mathrm{kg})$ & $72.5 \pm 10.7^{*}$ & $77.8 \pm 12.6^{*}$ & $82.6 \pm 8^{*}$ & 0.007 \\
\hline BMI $\left(\mathrm{kg} / \mathrm{m}^{2)}\right.$ & $22.2 \pm 1.6^{*}$ & $23.8 \pm 3 *$ & $27.5 \pm 4^{*}$ & 0.000 \\
\hline Body fat mass $(\mathrm{kg})$ & $8 \pm 2.2$ & $7.8 \pm 3.8$ & $10.6 \pm 2^{*}$ & 0.637 \\
\hline Muscular mass $(\mathrm{kg})$ & $39.6 \pm 8.9^{*}$ & $43.1 \pm 8.7^{*}$ & $35.2 \pm 3$ & 0.015 \\
\hline
\end{tabular}

Data recorded and analyzed were average values regardless gender and are specific to sport categories compared to control who showed specific difference to weight, BMI, and fat mass.

\section{Testosterone and MSTN measurement}

Anabolic steroid such as testosterone and muscle growth factor MSTN (GDF8) may play a key role to enhance athletic performance. With such factors available at optimum concentration, athletes may excel during sports and competitions. However, measurement of their concentration is not stable at all time, but varies due to training and need of the body to recover after intense exercise. Table 2 shows measurement of testosterone and GDF8 before and after one day training program in athletes participated in the study. 
Table 2. measurement of testosterone and MSTN (GDF8) in athletes at different periods of training program.

\begin{tabular}{|c|c|c|c|c|c|c|c|c|}
\hline & \multicolumn{4}{|c|}{ Testosterone $\mathrm{ng} / \mathrm{ml}$} & \multicolumn{4}{|c|}{ MSTN ng/ml } \\
\hline $\begin{array}{l}\text { Participants/ } \\
\text { Males } \\
\mathrm{N}=67\end{array}$ & $\begin{array}{l}\text { Before } \\
\text { exercise }\end{array}$ & $\begin{array}{l}\text { After } \\
\text { exercise }\end{array}$ & $\begin{array}{l}\text { After } 5 \\
\text { hours rest }\end{array}$ & Pvalue & $\begin{array}{l}\text { Before } \\
\text { exercise }\end{array}$ & $\begin{array}{l}\text { After } \\
\text { exercise }\end{array}$ & $\begin{array}{l}\text { After } 5 \\
\text { hours rest }\end{array}$ & Pvalue \\
\hline $\begin{array}{l}\text { Control } \\
\mathrm{N}=30\end{array}$ & $4 \pm 0.2$ & $4 \pm 0.21$ & $4 \pm 0.2$ & 0.005 & $6 \pm 0.3$ & $6 \pm 0.25$ & $6 \pm 0.27$ & 0.005 \\
\hline $\begin{array}{lr}\text { Sprinters } & \text { and } \\
\text { Endurance } & \\
\mathrm{N}=35 & \end{array}$ & $7 \pm 0.23$ & $3 \pm 1.1^{*}$ & $8 \pm 0.2^{*}$ & 0.005 & $5 \pm 0.7$ & $3 \pm 0.3^{*}$ & $2 \pm 0.78^{*}$ & 0.005 \\
\hline $\begin{array}{l}\text { Power athletes } \\
\mathrm{N}=32\end{array}$ & $8 \pm 0.31$ & $2 \pm 0.88^{*}$ & $9 \pm 0.1^{*}$ & 0.005 & $4 \pm 0.85$ & $2 \pm 0.25^{*}$ & $2 \pm 0.21 *$ & 0.005 \\
\hline $\begin{array}{l}\text { Participants/ } \\
\text { Females } \\
\mathrm{N}=36\end{array}$ & $\begin{array}{l}\text { Before } \\
\text { exercise }\end{array}$ & $\begin{array}{l}\text { After } \\
\text { exercise }\end{array}$ & $\begin{array}{l}\text { After } 5 \\
\text { hours rest }\end{array}$ & Pvalue & $\begin{array}{l}\text { Before } \\
\text { exercise }\end{array}$ & $\begin{array}{l}\text { After } \\
\text { exercise }\end{array}$ & $\begin{array}{l}\text { After } 5 \\
\text { hours rest }\end{array}$ & $P$ value \\
\hline $\begin{array}{l}\text { Control } \\
\mathrm{N}=20\end{array}$ & $2 \pm 0.19$ & $2 \pm 0.21$ & $2 \pm 0.2$ & 0.005 & $7 \pm 0.33$ & $7 \pm 0.35$ & $7 \pm 0.37$ & 0.005 \\
\hline $\begin{array}{ll}\text { Sprinters } & \text { and } \\
\text { Endurance } & \\
\mathrm{N}=20 & \end{array}$ & $3 \pm 0.23$ & $1 \pm 1.13 *$ & $4 \pm 0.3^{*}$ & 0.005 & $7 \pm 0.7$ & $4 \pm 0.5^{*}$ & $4 \pm 0.78 *$ & 0.005 \\
\hline $\begin{array}{l}\text { Power athletes } \\
\mathrm{N}=16\end{array}$ & $4 \pm 0.31$ & $2 \pm 0.6^{*}$ & $6 \pm 0.14 *$ & 0.005 & $6 \pm 0.85$ & $4 \pm 0.25 *$ & $3 \pm 0.98 *$ & 0.005 \\
\hline
\end{tabular}

Control in both genders were listed for comparison. None of them performed any exercise causing stress on their body.

\section{Genetic analysis and detection of polymorphism in MSTN gene}

The GDF8 maintains three coding exons responsible for MTCN production. We successfully amplified all three exons with partial sequence of intron 1. Blast results of obtained sequences showed exon 1 without change whereas point mutation at intron 1 at position 88-90 bp referred to as rs 11333758 where c.373+90delA. This SNP varied according to the allele and can be classified as wild type positive homozygous where both DNA strands kept (A) nucleotide, heterozygous where one (A) nucleotide is deleted, and negative homozygous where the (A) nucleotide is missing in both alleles. Functionality of this SNP was not widely reported [22]. Allele distribution and genotype of rs11333758 SNP among participants is illustrated in table 3 .

Table 3. allele distribution and genotype of rs11333758 SNP in athletes and control.

\begin{tabular}{|c|c|c|c|c|c|c|c|c|}
\hline \multirow[t]{2}{*}{ Groups } & \multirow[t]{2}{*}{$\mathrm{N}$} & \multicolumn{2}{|c|}{$\begin{array}{l}\text { Allele Frequency } \\
(\%)\end{array}$} & \multirow[t]{2}{*}{$\begin{array}{l}\text { p-Value Compared with } \\
\text { Control }\end{array}$} & \multicolumn{3}{|c|}{$\begin{array}{lr}\text { Frequency } & \text { percentage of } \\
\text { GDF8 } & \text { c.373+90delA } \\
\text { Genotype } & \end{array}$} & \multirow[t]{2}{*}{$\begin{array}{l}\mathrm{p} \text {-Value } \\
\text { Compared } \\
\text { with Control }\end{array}$} \\
\hline & & A & - & & AA & $\mathrm{A} /-$ & $(-/-)$ & \\
\hline Control & 50 & 85.5 & 14.5 & - & $\begin{array}{l}88 \\
(69.3)\end{array}$ & $\begin{array}{l}38 \\
(29.9)\end{array}$ & $\begin{array}{l}1 \\
(0.8)\end{array}$ & - \\
\hline $\begin{array}{l}\text { Sprinters and } \\
\text { Endurance }\end{array}$ & 55 & 73.6 & 26.4 & 0.014 & 57.8 & 29.6 & 13.6 & 0.001 \\
\hline Power athletes & 48 & 76.0 & 24.0 & 0.140 & 64.7 & 28.5 & 6.8 & 0.060 \\
\hline
\end{tabular}

Significant differences were also found in genotype frequencies in relation to gender listed in table 4.

Table 4. difference in allele frequency within the same gender.

\begin{tabular}{|l|l|l|l|l|}
\hline & AA (\%) & A/- (\%) & $(-/-)(\%)$ & \\
\hline Male athletes & 65.3 & 25.7 & 9.0 & 0.032 \\
\hline Control & 64.7 & 35.3 & 0 & \\
\hline Female athletes & 54.8 & 34.1 & 11.1 & 0.037 \\
\cline { 1 - 3 } Control & 74.6 & 23.7 & 1.7 & \\
\hline
\end{tabular}

\section{Discussion}


Among genetic factors affecting athletic performance, MSTN (GDF8) drew attention since it represents the negative control over muscles growth and exerts its influence on adipose tissues influencing human physical activity [23]. Among many factors affecting athletic performance such as nutrition, environmental factors, physiological factors, neural and cardiac fitness, anabolic hormones come to play a key role with their direct influence on muscles fiber synthesis and recovery from intensive training. It seems there is a relationship between MSTN and testosterone in enhancing athletic performance. During our study we found there is a significant decrease in testosterone levels and MSTN in athletes after intensive training which can be attributed to the need of body to increase energy levels within cells to cope with stress of exercise. However, data obtained after 5 hours of rest showed high elevation of testosterone in participants with continued lowering of MSTN suggesting negative relationship between them. With such relationship exist, the body can speedup recovery period and produce higher muscle mass as training program continues. This can be considered as crucial factor differentiating elite athletes from the others in future selection programs.

From another point of view, genetic factors have been considered during the research. The main focus on MSTN gene analysis showed a significant difference between athletes and control. Comparing deletion rate between control and athletes, we found it is higher in athletes $29.0 \%$ than control group $14.0 \%$, especially in endurance athletes which was $38.2 \%$ $(\mathrm{p}<0.05)$. The negative homozygous genotype $(-/-)$ was significantly higher in endurance athletes rated $23.5 \%$ and in power athletes measured to be $10 \%$ than in the controls with respect to gender $(\mathrm{p}<0.05)$. Presence of the novel SNP rs 11333758 in athletic group suggest exceled endurance performance status in elite athletes and seems to be more frequent in Iraqi athletes. Previous reports showed that this SNP is associated with production of peak power during muscle contractions [24], thicker biceps [25], and low body fat [23].

\section{Conclusions}

We found during this work the presence of negative relationship between testosterone and MSTN (GDF8). An elevated concentration of testosterone lowered significantly MSTN levels in blood allowing faster muscle recovery and synthesis of more muscle fibers for bigger muscles. With presence of different alleles of MSTN gene, the null genotype was the least percentage among athletes, but associated with increasing muscle size and enhancing athletic performance. This genotype was significantly higher in male athletes than females, and in general higher in athletes compared to control. 


\section{References}

Richter EA, Hargreaves M. Exercise, GLUT4, and Skeletal Muscle Glucose Uptake. Physiol Rev [Internet]. 2013;93(3):993-1017. Available from: http://physrev.physiology.org/cgi/doi/10.1152/physrev.00038.2

Bonaldo P, Sandri M. Cellular and molecular mechanisms of muscle atrophy. Dis Model Mech [Internet]. 2013;6(1):25-39. Available from: http:/ / www.pubmedcentral.nih.gov/articlerender.fcgi?artid=3529336\&tool $=$ pmcentrez\&rendertype $=$ abstract

Maughan, RJ, Watson, JS, and Weir, J. Strength and cross-sectional area of human skeletal muscle. J Physiol 338: 37-49, 1983.

Herman, J.R.; Rana, S.R.; Chleboun, G.S.; Gilders, R.M.; Hageman, F.C.; Hikida, R.S.; Kushnick, M.R.; Ragg, K.E.; Staron, R.S.; Toma, K. Correlation Between Muscle Fiber Cross-Sectional Area and Strength Gain Using Three Different ResistanceTraining Programs In College-Aged Women. J. Strength Cond. Res. 2010, 24, 1.

Jones, E.J.; Bishop, P.A.; Woods, A.K.; Green, J.M. Cross-Sectional Area and Muscular Strength: A Brief Review. Sports Med. 2008, 38, 987-994.

Hackett, D.A.; Johnson, N.A.; Chow, C.M. Training Practices and Ergogenic Aids Used by Male Bodybuilders. J. Strength Cond. Res. 2013, 27, 1609-1617.

Srikanthan, P.; Horwich, T.B.; Tseng, C.H. Relation of Muscle Mass and Fat Mass to Cardiovascular Disease Mortality. Am. J. Cardiol. 2016, 117, 1355-1360.

Burrows, R.; Correa-Burrows, P.; Reyes, M.; Blanco, E.; Albala, C.; Gahagan, S. Low muscle mass is associated with cardiometabolic risk regardless of nutritional status in adolescents: A cross-sectional study in a Chilean birth cohort. Pediatr. Diabetes 2017, 18, 895-902.

Michal Krzysztofik, Michal Wilk, Grzegorz Wojdała and Artur Goła's. Maximizing Muscle Hypertrophy: A Systematic Review of Advanced Resistance Training Techniques and Methods. Int. J. Environ. Res. Public Health 2019, 16, 4897; doi:10.3390/ijerph 16244897.

McPherron AC, Lawler AM, Lee SJ 1997 Regulation of skeletal muscle mass in mice by a new TGF- $\beta$ superfamily member. Nature. 387:83-90.

Rodgers BD, Garikipati DK 2008 Clinical, agricultural, and evolutionary biology of myostatin: a comparative review. Endocr Rev. 29:513-534.

Schuelke M, Wagner KR, Stolz LE, Hu" bner C, Riebel T, Ko" men W, Braun T, Tobin JF, Lee SJ 2004 Myostatin mutation associated with gross muscle hypertrophy in a child. N Engl J Med 350:2682-2688.

Szulc P., Schoppet M., Goettsch C., et al. Endocrine and Clinical Correlates of Myostatin Serum Concentration in Men-the STRAMBO Study. J Clin Endocrinol Metab, 2012, 97(10):3700 -3708.

Kawada S, Tachi C, Ishii N (2001) Content and localization of myostatin in mouse skeletal muscles during aging, mechanical unloading and reloading. J Muscle Res Cell Motil 22: 627-633

Clay C a, Perera S, Wagner JM, Miller ME, Nelson JB, Greenspan SL. Physical function in men with prostate cancer on androgen deprivation therapy. Phys Ther. 2007;87(10):1325-33.

Shin MJ, Jeon YK, Kim IJ. Testosterone and Sarcopenia. World J Mens Health. 2018;36(3):192.

Arik Davidyan, Keith Baar, Sue C. Bodine. The Maintenance of Muscle Mass Is Independent of Testosterone in Adult Male Mice. bioRxiv, 2020: https://doi.org/10.1101/2020.09.24.311266

Filonzi, L.; Franchini, N.; Vaghi, M.; Chiesa, S.; Marzano, F.N. The potential role of myostatin and neurotrans mission genes in elite sport performances. J. Biosci. 2015, 40, 531-537.

Ginevi`cien'e V., Jakaitien'e A., Pranckevi`cien'e E., Milašiusand K. and Utkus A. Variants in the Myostatin Gene and Physical Performance Phenotype of Elite Athletes. Genes 2021, 12, 757.https://doi.org/10.3390/genes12050757.

Kawada S., Okuno M. and Ishii N. Testosterone Causes Decrease in the Content of Skeletal Muscle Myostatin. International Journal of Sport and Health Science Vol.4, 4448, 2006. http://www.soc.nii.ac.jp/jspe3/index.htm.

Abdul Razzaq Jabr Al Majidi, Rafia S. Fathi, Rehab S. Ramadhan. A molecular insight in sport and athletic alpha - actin3 gene in students of Physical Education Faculty 
and bodybuilders. Periodicals of Engineering and Natural Sciences. 2021, Vol. 9, No. 3, pp.699-714.

Karlowatz, R.J.; Scharhag, J.; Rahnenführer, J.; Schneider, U.; Jakob, E.; Kindermann, W.; Zang, K.D. Polymorphisms in the IGF1signalling pathway including the myostatin gene are associated with left ventricular mass in male athletes. Br. J. Sports Med. 2011, 45, 36-41.

Guo T., McPherron A. C., Jou W., Chanturiya T., Portas J., Gavrilova O. Myostatin Inhibition in Muscle, but Not Adipose Tissue, Decreases Fat Mass and Improves Insulin Sensitivity. PLoS ONE, 2009. Volume 4 (3): e4937.

Santiago, C.; Ruiz, J.R.; Rodriguez-Romo, G.; Fiuza-Luces, C.; Yvert, T.; Gonzalez Freire, M.; Gómez-Gallego, F.; Morán, M.; Lucia, A. The K153R polymorphism in the myostatin gene and muscle power phenotypes in young, non-athletic men. PLoS ONE 2011, 6, e16323.

Khanal, P.; He, L.; Herbert, A.J.; Stebbings, G.K.; Onambele-Pearson, G.L.; Degens, H.; Morse, C.I.; Thomis, M.; Williams, A.G. The Association of Multiple Gene Variants with Ageing Skeletal Muscle Phenotypes in Elderly Women. Genes $2020,11,1459$. 